\title{
Huisarts en complexe zorgvraag
}

\section{Ervaring met integraal samenwerken tussen de eerste lijn, de gemeente en welzijn}

\author{
Hedwig Vos
}

Published online: 11 February 2019

(C) The Author(s) 2019

In dit artikel beschrijf $i k$ een patiëntencasus waarmee $i k$ wil laten zien waar huisartsen tegenaanlopen in de samenwerking met het sociale domein, ziekenhuizen en de geestelijke gezondheidszorg, en hoe ik daar als huisarts mee omga. U kent de huisarts waarschijnlijk als een zorgprofessional die door middel van consulten en huisvisites problemen probeert op te lossen. In dit artikel laat ik zien hoe een andere kijk en een andere aanpak uitwerken bij complexe problematiek.

\section{Inleiding}

Huisartsen worden in de spreekkamer geconfronteerd met de maatschappij daarbuiten. De problemen van de patiënt zijn vaak multifactorieel bepaald en kunnen worden veroorzaakt door een combinatie van vaak pre-existente psychische problemen, zoals persoonlijkheidsproblematiek en een traumatische voorgeschiedenis, de aanwezigheid van een verstandelijke beperking, een zwak steunsysteem en uitgeputte mantelzorgers, gezondheidsproblemen met daarbij maatschappelijke problemen, zoals schulden, huisvestingsproblemen, relatieproblemen en sociaal isolement. De zwaarte van de zorgvraag kan vaak fors zijn, terwijl bij uitvragen van de relevante leefgebieden blijkt dat er sprake is van problemen die veroorzaakt worden door maatschappelijke problemen als schulden, werkloosheid, slechte huisvesting of eenzaamheid. Hoewel buiten de spreekkamer ontstaan, dragen deze problemen wel degelijk bij aan een zwaardere en vaak complexe zorgvraag. Zo veroorzaakt werkloosheid een slechtere gezondheid [1], die verbetert als iemand weer betaald werk vindt [2].

Dr. H. Vos $(\bowtie)$

ELAN - Extramuraal Leids Academisch Netwerk, LUMC, Den

Haag, Nederland

H.M.M.Vos@lumc.nl
Slechte huisvesting zorgt voor een slechtere fysieke en mentale gezondheid, en de gezondheid verbetert als geïnvesteerd wordt in huisvesting [3]. Schulden hebben een grote invloed op de gezondheid en veroorzaken depressies en een minder gezonde leefstijl [4]. Dergelijke problemen komen vaker voor bij mensen met een lagere sociaaleconomische status (SES) en dragen daardoor bij aan de grote sociaaleconomische gezondheidsverschillen die in Nederland nog steeds bestaan [5]. Deze verschillen zijn de afgelopen decennia alleen maar groter geworden [6], waardoor het verschil in levensverwachting tussen een hoge en lage SES voor mannen momenteel 6 jaar en voor vrouwen 6,7 jaar is [7]. Ook stapelen gezondheidsproblemen en sociale problemen zich bij kwetsbare groepen vaak op, niet alleen bij individuen, maar ook in wijken [5]. De oplossing voor deze problemen is nog niet zo gemakkelijk te vinden en bestaat meestal niet uit het voorschrijven van een pilletje.

\section{Casus}

Mijn patiënt is een man van 58 jaar, bekend met COPD (longblaasjesverlies), recidiverende depressies, een reumatische aandoening met chronische gewrichtspijn en recentelijk een pleura-emfyseem (pus tussen de longbladen), waarvoor meerdere operaties nodig waren, met als gevolg pijnklachten. Hij heeft enkele jaren geleden een roofoverval in zijn huis meegemaakt. Sindsdien ervaart hij een toename van zijn depressieve klachten en angstklachten, die passen bij een posttraumatische stressstoornis. Door die stoornis durft hij niet naar plekken te gaan waar het druk is en gaat hij zo min mogelijk naar buiten. Hij rookt drie tot vier pakjes sigaretten per dag. Hij drinkt dagelijks meerdere eenheden alcohol. 
Vanwege de fysieke en psychische klachten heeft hij zijn onderneming moeten sluiten. Door een gebrek aan inkomen heeft hij schulden opgebouwd.

Ik zie hem geregeld op mijn spreekuur. Vorig jaar meldde hij zich bij mij met depressieve klachten en gaf hij bij doorvragen aan dat hij schulden had, maar dat hij weinig hoop had dat daar iets aan gedaan kon worden. Ik heb een sociaal-psychiatrisch verpleegkundige (SPV) van het project 'GGZ in de wijk' van de gemeente Den Haag gevraagd contact met hem op te nemen. Na enkele gesprekken met de SPV is een schuldsaneringstraject aangevraagd. De SPV vroeg mij hem formeel naar de ggz te verwijzen voor de behandeling van zijn depressie, die inmiddels met suïcidale gedachten en ook forse angstklachten gepaard ging. $\mathrm{Na}$ een telefonische intake werd hij niet in zorg genomen. In de brief naar mij staat dat daar geen indicatie voor bestond, en hem is verteld dat hij eerst moet stoppen met zijn alcoholgebruik. Dat doet hij niet, want hij beschouwt zijn alcoholgebruik niet als een groot probleem. De psycholoog naar wie ik hem wil doorverwijzen geeft aan dit jaar geen patiënten meer te accepteren die zijn verzekerd bij de zorgverzekeraar waar mijn patiënt is ingeschreven - de bodem van het toegestane budget komt in zicht. Het is pas augustus ...

Het volgende contact met hem gaat over het verlies van zijn auto vanwege het schuldsaneringstraject dat gaat starten. Het bezit van een auto is daarbij niet toegestaan. Hij vertelt veel pijn te hebben, is benauwd, leeft geïsoleerd, heeft weinig uitzicht op verbetering en voelt zich nog veel depressiever. Hij geeft aan dat hij eigenlijk alleen aan mij als huisarts eerlijk durft te vertellen hoe slecht het met hem gaat. Behandeling bij de pijnpoli heeft weinig effect.

Ik nodig hem uit voor een lang gesprek op de praktijk aan het eind van het spreekuur, om te kijken of er aangrijpingspunten zijn om hem te helpen. Hij geeft aan zich nutteloos te voelen en weinig uitzicht te hebben op verbetering. Er spelen meerdere trauma's uit het verleden en hij leeft erg geïsoleerd, en heeft eigenlijk alleen maar contact met enkele betrokken buren, een familielid, de SPV en mij. Hij durft nauwelijks naar buiten te gaan. Toch geeft hij aan dat hij fysiek wel in staat zou zijn om iets te doen. Hij heeft altijd met mensen gewerkt en dan had hij het gevoel dat hij nuttig was voor de maatschappij. Dat wil hij graag weer voelen, want hij is duidelijk op zoek naar zingeving.

We besluiten dat zijn angstklachten op dit moment de grootste belemmering vormen om uit zijn isolement te komen. Per 1 januari zal ik hem aanmelden bij de psycholoog voor een behandeling van zijn posttraumatische stressstoornis en ik bespreek zijn casus tijdens een multidisciplinair overleg in de wijk, het zogenaamde Gestructureerde Periodieke Overleg (GPO), waaraan een wijkverpleegkundige, een welzijnscoach, een apotheker, een specialist ouderengeneeskunde, een SPV en een ergotherapeut deelnemen.

\section{Beschouwing}

De casus laat zien dat maatschappelijke problemen vaak samengaan met somatische en psychische klachten, en elkaar bovendien wederzijds beïnvloeden. In consulten met mensen met complexe problemen, die vaak langer duren dan de slechts 10 tot 20 minuten die de huisarts tot zijn beschikking heeft, komen vaak maatschappelijke problemen aan de orde. In de beschreven casus is de relatie tussen sociale factoren en ziekte zonneklaar. Het is duidelijk dat ik als huisarts zijn problemen niet in mijn eentje samen met de patiënt kan oplossen. Andere bij deze casus betrokken partijen zijn de gemeente, het welzijnswerk, de ggz en het ziekenhuis.

Vaak uiten mensen met complexe problemen hun klachten door middel van somatische problemen, zoals chronische pijn, benauwdheid of andere vaak onbegrepen chronische klachten. Tegen de tijd dat mensen somatische klachten ontwikkelen en bij de huisarts aan de bel trekken bestaan de problemen vaak al langere tijd, waardoor ze nog veel complexer zijn geworden. Tegelijkertijd kan de huisarts de problemen vaak zien aankomen. De huisarts kent immers de context in de gezinnen, maar ook in de wijk.

De kennis van de huisarts is waardevol. In verschillende gemeenten worden weliswaar wijkscans gemaakt, maar de kennis van de huisarts is vaak veel gedetailleerder en loopt in signalering ook voor op de wijkscans. Van deze kennis, vooral die op wijkepidemiologisch niveau, zouden gemeenten gebruik moeten maken bij het vormgeven van gezondheids- en preventiebeleid door aan huisartsen te vragen tegen welke problemen zij aanlopen, zowel individueel als via regionale huisartsenorganisaties. Dit kan tijdens gesprekken gebeuren, maar ook heel goed via periodieke vragenlijsten per e-mail. En er moet gezocht worden naar mogelijkheden voor structurele samenwerking tussen huisartsen, de gemeente en de GGD, en als het kan financiering daarvoor (al is het maar voor eventuele overlegtijd).

Preventie is om meer dan een reden belangrijk. Als de problemen langer duren en in complexiteit toenemen vindt hulpverlening vanuit welzijn vaak onvoldoende aansluiting bij de persoon die wel degelijk om hulp vraagt. De problemen zijn dan inmiddels vaak te complex voor het sociale domein geworden, waardoor de hulpverlening geïntensiveerd moet worden en er veel meer interdisciplinaire samenwerking moet gaan plaatsvinden, met bijvoorbeeld maatschappelijk werkers, de ggz, politie, thuiszorg, tweede lijn en huisarts. Met alle financiële consequenties en impact op de tijdsbesteding van de betreffende hulpverleners van dien. Hierin speelt de huisarts dus een grote rol, want de die is er vaak vroeg bij.

Door samen te werken met het sociale domein kunnen problemen in een vroeg stadium aangepakt worden. Voorbeelden hiervan zijn Welzijn op recept (zie het kader) [8], casuïstiek bespreken in Gestruc- 
tureerde Periodieke Overleggen (GPO) met huisarts en verpleegkundige (wijk- of praktijkverpleegkundige) en een ouderenconsulent vanuit welzijn [9], en samenwerken met Sociale Wijkteams of Wmo-teams, wijkcentra en (onafhankelijke) wijkverpleegkundigen, voor zover aanwezig.

Ikzelf werk op wijkniveau al samen met professionals vanuit zorg en welzijn. Als je mensen kent vanuit welzijn, de gemeente en andere organisaties is de drempel om te overleggen of een melding te doen niet zo hoog. Met wie je kunt samenwerken en wie je kunt bellen zal per wijk en per gemeente verschillen, afhankelijk van de problematiek in de wijk (bijvoorbeeld veel ouderen, veel dak- en thuislozen of veel mensen met schulden). Vaak hebben gemeenten een website met de sociale kaart of is deze in het wijkcentrum bekend. Bovendien hebben steeds meer huisartsen ervaring met het opzetten van een overlegstructuur.

\section{Conclusie}

Ik heb willen laten zien dat huisartsen complexe problemen in de spreekkamer krijgen die niet door hen alleen kunnen worden opgelost. Samenwerking is dus noodzakelijk. Voor huisartsen is het een uitdaging om de sociale kaart te kennen, zodat patiënten gericht doorverwezen kunnen worden als ze met een maatschappelijk probleem kampen. Maar preventie van en vroege interventie bij maatschappelijke problemen zijn ook belangrijk. Die worden mogelijk door huisartsen, gemeenten en GGD aan elkaar te koppelen, zodat de kennis van de wijkepidemiologie die de huisarts heeft voor het lokale volksgezondheidsbeleid gebruikt kan worden. Daarnaast is het belangrijk dat er samengewerkt wordt tussen de nulde en eerste lijn om tot een daadwerkelijk integrale zorg te komen, vooral voor de meest kwetsbare mensen. Huisartsen moeten hierin uiteraard wel gefaciliteerd worden door de gemeente en/of zorgverzekeraar, in tijd en geld. Ik heb laten zien dat er meer te bereiken is voor de meest kwetsbare mensen in onze maatschappij door langere intensieve gesprekken tussen huisarts en patiënt, samenwerking met de gemeente en welzijn, en doorzetten richting ggz. Dit kost echter wel veel tijd, eigenlijk meer dan beschikbaar is.

Open Access This article is distributed under the terms of the Creative Commons Attribution 4.0 International License (http://creativecommons.org/licenses/by/4.0/), which permits unrestricted use, distribution, and reproduction in any medium, provided you give appropriate credit to the original author(s) and the source, provide a link to the Creative Commons license, and indicate if changes were made.

\section{Literatuur}

1. Mathers CD, Schofield DJ. The health consequences of unemployment: the evidence. MedJAust. 1998;168:178-82.

2. Carlier BE, Schuring M, Lötters FJ, et al. The influence of re-employment on quality of life and self-rated health,

\section{Enkele voorbeelden}

\section{Welzijn op recept}

Het doel van Welzijn op recept is het verminderen van psychosociale klachten van mensen die bij de huisarts komen. Welzijnsorganisaties en eerstelijnszorgvoorzieningen ontwikkelen lokale welzijnsarrangementen, waar mensen naar doorverwezen worden. Deze bestaan uit interventies die het welbevinden verhogen, zoals creatieve of sportieve activiteiten en vrijwilligerswerk. Welzijn op recept vindt in vele gemeenten in Nederland plaats [8].

\section{Gestructureerd Periodiek Overleg (GPO)}

Het GPO is een onderdeel van een cyclisch proces van hulpverlening, waarbij steeds de problemen en wensen van de oudere geïnventariseerd worden. Met elkaar worden passende zorgdoelen geformuleerd of bijgesteld, en aangewezen interventies afgesproken en geëvalueerd. Bij zelfstandig wonende ouderen bestaat het kernteam uit huisarts en verpleegkundige (wijk- of praktijkverpleegkundige) en nemen ook op indicatie paramedici, SO en/of apotheker deel. Vaak is een ouderenconsulent vanuit welzijn aanwezig [9].

\section{Toegang tot het sociaal domein}

Sinds de decentralisaties van de Wet maatschappelijke ondersteuning (Wmo), de Jeugdwet en de Participatiewet in 2015 hebben de gemeenten als taakstelling het organiseren van de toegang tot collectief gefinancierde zorg en ondersteuning. Per gemeente is dit anders georganiseerd en het is dus onmogelijk om deze toegang in z'n algemeenheid te omschrijven.

a longitudinal study among unemployed persons in the Netherlands. BMCPublic Health. 2013;13:503.

3. Thomson H, Thomas S, Sellstrom E, etal. Housing improvements for health and associated socio-economic outcomes. Cochrane Database Syst Rev. 2013; https://doi.org/10. 1002/14651858.cd008657.pub2.

4. Turunen E, Hiilamo H. Health effects of indebtedness: a systematic review. BMCPublic Health. 2014;14:489.

5. Hilderink HBM, Verschuuren M. Volksgezondheid Toekomst Verkenning 2018: een gezond vooruitzicht. Bilthoven: RIVM; 2018.

6. Mol GD, Lisdonk EH van de, Smits JP, et al. A widening health gap in general practice? Socio-economic differences in morbidity between 1975 and 2000 in The Netherlands. Public Health. 2005;119:616-25.

7. CBS. Gezonde levensverwachting; opleiding. Statline 18 januari 2016. Den Haag: CBS, 2018. https:// opendata.cbs.nl/statline/\#/CBS/nl/dataset/71885ned/ table?ts=1549399687807. Geraadpleegd op 5 februari 2019 .

8. Movisie. Welzijn op recept. Utrecht: Movisie. 2015. https:// www.movisie.nl/esi/welzijn-recept. Geraadpleegd op 5 februari2019.

9. Landelijke Adviesgroep Eerstelijnsgeneeskunde voor Ouderen. Proactieve samenhangende zorg. https://laego. nhg.org/proactieve-samenhangende-zorg. Geraadpleegd op 5 februari 2019. 